\title{
Developing Software for Village Financial Management Through the Implementation of Law No. 6 Year 2014 in the Direction of "Good Village Governance"
}

\author{
Puji Handayati, Dodik Djuliardi, Nurika Restuningdyah, Vega, and Sriyani \\ Mentari \\ State Unversity of Malang
}

\section{Abstract}

The national development planning system is known as a unity of development planning procedures that will result in long-term, medium-term and year-long development undertaken by state and community-level providers at the central and regional levels. Implementation of autonomy for the village will be a power for the

Corresponding Author:

Puji Handayati

puji.handayati.fe@um.ac.id

Received: 23 January 2018

Accepted: 5 April 2018

Published: 23 April 2018

Publishing services provided by Knowledge $\mathrm{E}$

(c) Puji Handayati et al. This article is distributed under the terms of the Creative Commons Attribution License, which permits unrestricted use and redistribution provided that the original author and source are credited.

Selection and Peer-review under the responsibility of the 1st IRCEB Conference Committee. village government to administer, manage and administer its own household, as well as increase the burden of village responsibilities and responsibilities, yet the implementation of the government should still be accounted for. Accountability in question is responsible for the management of village budgets. For now the common obstacle felt by most villages is related to the limitations in village finances. Often the Village Revenue and Expenditure Budget (APBDes) is not balanced, between receipts and expenditures. Such facts are caused by four major factors (Hudayana and FPPD, 2005). First: the village has a small revenu and its source of income is very dependent on very little aid. Second: village people's welfare is low. Third: the low operational funds of the village to run the service. Fourth: that many development programs enter the village, but only managed by the service. The purpose of this study is to develop village financial management software implementation of Law no 62014 to realize Good Village Governance. This village finance software will accommodate in detail the tax calculations to be paid by the village treasurer.

Keywords: Village Financial Management, Good Village Governance

\section{Background}

Nowadays, the Indonesian government is continuously working to improve the implementation of the national development system. The National Development Planning

S OPEN ACCESS 
signal for a better change of development in Indonesia. The national development planning system is a unity of development planning procedures that will result in longterm, medium-term and year-long development undertaken by state and communitylevel providers at the central and regional levels. Implementation of autonomy for the village will be a power for the village government to administer, manage and administer its own household, as well as increase the burden of village responsibilities and responsibilities, but the implementation of the government should still be accounted for. Accountability in question is responsible for the management of village budgets. For now the common obstacle felt by most villages is related to the limitations in village finances. Often, the Village Revenue and Expenditure Budget (APBDes) is not balanced, between receipts and expenditures. Such facts are caused by four major factors (Hudayana and FPPD, 2005). First: the village has a small APBDes and its source of income is very dependent on very little aid. Second: village people's welfare is low. Third: the low operational funds of the village to run the service. Fourth: that many development programs enter the village, yet only managed by the institution.

The existence of Law No. 6 of 2014 on the Village brings its own opportunities and challenges. Opportunities to realize a prosperous village are more open, because this law has regulated $10 \%$ of the state budget disbursed to the village. With the budget, villages are given the authority to use the existing budget in order to realize a prosperous village. Like the two sides of the coin, between hopes and challenges can not be separated. APBN Budget of $10 \%$ is certainly not a small amount for the development of the village, therefore the arrangement and management of the budget becomes an inseparable challenge. Potential abuse or "CORRUPTION" will always be present. Learning from experience, decentralization that gives grassroots "grassroots" authority is perceived as a hasty policy. Especially referring the scientists who joined the International Crisis Group (ICG) called the decentralization policy that began implemented in 1999 ago as "The Big Bang" (Nugroho in Irawati: 2010). Certainly this new Village Law must be outside the black box of previous local autonomy errors. There are at least 5 (five) strategic issues in the construction of the Village Law, namely 1) Village Development, 2) Finance, Assets and BuMDesa, 3) Rural Development, 4) Inter-Village Cooperation, 5) Village Community Institutions. Concerning the issue of village development, it is conceived to improve the welfare of the village community and the quality of human life and poverty alleviation through the provision of basic needs, the construction of village facilities and infrastructure, the development of local economic potential, and the sustainable use of natural resources and environment. 
Rural development also promotes togetherness, kinship, and mutual cooperation in order to realize the mainstream of peace and social justice.

Associated with the administrative and administrative capabilities of village government officials are still minimal. Then, the system of accountability and supervisory institutions are still weak, including the community has not been critical of the management of revenue and expenditure budget villages. Guidelines on Village Financial Management as the implementing regulations of Law No.32 / 2004 on Regional Government. In the Permendagri mentioned that the management of village finances implemented by village tools, among others, the Village Treasurer and Technical Executive of Village Financial Management (PTPKD). While the documents mentioned in the Permendagri which should be used in the management of village finances are: general ledger, auxiliary book details of the object of acceptance; auxiliary copies of item details of expenditures; daily cash register.

Preliminary research results have been done where at the time of socialization of village financial management to 7500 village heads in East Java in 2014 found a picture that the very lack of ability of the village head and his apparatus in the management and administration of village finances today. The average level of education of the village head and his apparatus is junior and senior high school (SMP / SMA), so the need for skills improvement through training and assistance related to the management and administration of village finances that have been mandated by the Law.

Village fund management systems managed by the village government include the collection and accountability mechanisms referring to Law Number 33 Year 2004 on Fiscal Balance between Central Government and Local Government. In the regulation explained that the funding of development carried out by the local government including the village government embraced the principle of money follows function which means that funding follows the government functions that become obligations and responsibilities of each level of government. Under these conditions fund transfers are important to maintain / ensure the achievement of minimum public service standards (Simanjuntak, 2002). The consequence of the statement is that decentralization of authority must be accompanied by fiscal decentralization. The realization of fiscal decentralization in the regions resulted in the existence of a financial balance fund between kabupatens and villages known as Village Fund Allocation (ADD). In the current system of governance, the village has a strategic role in assisting local governments in the governance process, including development. All this is done as a concrete step local government supports the implementation of regional autonomy in the region. Good governance is an institutional framework for strengthening village 
autonomy, because substantively decentralization and village autonomy are not only a matter of dividing authority between levels of government, but rather as an effort to bring the country closer to society. Local government will not be strong and autonomy will not be meaningful and beneficial to local people if not supported by transparency, accountability, participation and responsiveness.

\section{Research Objective}

The purpose of this study is to develop village financial management software implementation of Law No. 6 of 2014 that is an effort toward Good Village Governance.

\section{Theoretical Backround}

\subsection{Village}

Village according to Law No. 6 of 2014 concerning the village is a "village and a traditional village called another name, hereinafter referred to as the Village is a legal community unity that has the boundaries of the territory authorized to regulate and administer government affairs, the interests of local communities based on community initiatives, origin rights and traditional rights recognized and respected within the system of government of the Unitary State of the Republic of Indonesia. "(Law No. 6 article 1, paragraph 1 year 2014).

Furthermore, Widjaja (2003) defines the village as a legal community unit which has its original structure based on special privileges of origin. The basic thinking in the Village Government is diversity, participation, indigenous autonomy, democracy and community empowerment ". In that sense it has been explained that the village is a self-governing community. Thus, the village has the authority to regulate and manage the interests of the community by taking into account the condition and socio-culture in the village, the position of the village that has the original autonomy position is very strategic so it needs a balanced attention to the supervision of Regional Autonomy.

\subsection{Village Development}

Village development by the World Bank in 1970 is a development associated with raising living standards to reduce poverty in rural areas. In village development there are several main factors that are often used in rural development. The most common 
factor is focused on the economic, social and environmental environments of human beings in supporting the improvement of living standards or the welfare of the people. In addition, it is important to note that the local community traditions, environmental quality, and adaptation of village apparatus. Factors used to measure the development of the village are the unemployment rate in the village, residence, birth rate, average minimum wage, number of businesses, the number of working commuters, the number of villagers who own the car, the number of village communities who study, education index, number of people unable to work due to illness, age, turnover owned by village communities, total migration revenues. In the development process, a coherent system in which one factor affects the other. (Source: Factor affecting development of rural areas, 2016).

\subsection{Village in Development Planning Frame}

Law Number 25 Year 2004 regarding National Development Planning System has stipulated the National Long Term Development Plan which is the elaboration of the objective of the establishment of Indonesian state government. Villages that have the right of origin and traditional rights to regulate and manage the interests of the community play a role in realizing the ideals of independence under the 1945 Constitution of the State of the Republic of Indonesia need to be protected and empowered to be strong, advanced, independent and democratic so as to create a foundation firm in implementing governance and development towards a just, prosperous, and prosperous society. Therefore, the objective of stipulation of village arrangements in this Law is further elaboration of the provisions as meant in Article 18 paragraph (7) and Article $18 \mathrm{~B}$ paragraph (2) of the 1945 Constitution of the State of the Republic of Indonesia.

\subsection{Principles of Village Financial Management}

Principle is the value that animates the Village Financial Management. The principle gives birth to the principles that form the basis and should be reflected in every action of Village Financial Management. Principles and principles are useless if they do not materialize in action. As per Permendagri No. 113 Year 2014, Village Finance is managed on the basis of principles that is: transparency, accountability, participatory, and orderly administration. 


\section{Research Methods}

\subsection{Types of Research}

This research is a development research by Gay (1990). Research \& Development is an attempt to develop an effective product for school use, and not to test the theory.

Borg and Gall (1983: 772) defined that research \& development is as follows: Educational Research and development (R \& D) is a process used to develop and validate educational products. The steps of this process are usually referred to as the $R \& D$ cycle, which consists of studying the research findings, the field testing it in the setting where it will be used eventually, and revising it to correct the deficiencies found in the filed-testing stage. In more rigorous programs of $R \& D$, this cycle is repeated until the field-test data indicate that the product meets its behaviorally defined objectives.

\subsection{Data Analysis Technique}

For qualitative data, analysis is an analysis of suggestions, responses, and criticism from the validator, while for the analysis of quantitative data used percentage analysis technique by the formula:

$$
P=\frac{\sum x}{\sum x_{1}} \times 100 \%
$$

\subsection{Description}

$\mathrm{P}=$ Percentage

$\sum \mathrm{x}=$ Jumlah jawaban seluruh responden dalam 1 item

$\sum \mathrm{x}_{1}=$ Jumlah jawaban ideal dalam 1 item

After being analyzed, then, to determine the conclusion of each validated item is applied criteria:

a. Implementation stage is done in the second year that is implementation of mentoring and training of the use of tutorial book to operate siskeudes (village apparatus in 352 villages in Pasuruan Regency). At this stage, the role of the partner is support during the training of the village apparatus and evaluation of the tutorial book that has been implemented.

b. The outcomes of this research are international journals and tutorial books on the management of village finance 
TABLE 1: Validation Criteria.

\begin{tabular}{lc} 
ANSWER & CRITERIA \\
$80-100$ & Valid \\
$60-79$ & Quite Valid \\
$40-59$ & Less Valid (Revision) \\
$0-39$ & invalid (Revision) \\
\hline Source: Sudjana (2005) &
\end{tabular}

Table of contents of the village finance management tutorial book include: Brief Information on Village Finance, a Closer Look at the Village Finance System "SISKEUDES", General Cash Book, Payment Request Letter, Deposit Receipt, Monthly Cash Statement Report, Beneficiary Cash Book of Object Reception Details, and Cash Book of Details of Object Spending.

\subsection{Research Findings}

Pasuruan Regency is one of a district in East Java Province, Indonesia. The central government is located in Pasuruan City. The regency is bordered by Sidoarjo Regency and Java Sea in the north, Probolinggo regency in the East, Malang regency in the south, Batu Town in the southwest, and Mojokerto regency in the west. This district is known as the industrial area, agriculture, and tourist destination. The Tengger Highlands complex with Mount Bromo is a major tourist attraction.

The geographical location of Pasuruan regency is in a very strategic position since its regional line is also the main route of Surabaya - Malang and Surabaya - Banyuwangi economy. It is beneficial in economic development and opens up opportunities for infestation in Pasuruan. Pasuruan Regency has a total area of 147,401.50 Ha (3.13\% of East Java Province) consists of 24 Districts, 24 Sub-districts, 341 Villages and 1,694 Villages. This regency has one of the main industrial areas in East Java, Pasuruan Industrial Estate Rembang (PIER). The main industries in this regency are Sampoerna in Pandaan, Matsushita (Panasonic), Cheil Jedang Indonesia Rejoso and PT. Nestle Indonesia in Kejayan. This region is very popular in East Java because it is one of the driving force of East Java economy.

In order to create a good village accounting management system, responsible, where the amount of village funds provided in Pasuruan reached Rp 215 billion more, while the village budget funds ranged from Rp 143 billion and profit sharing of Rp 28 
billion more. Thus, the village fund that is managed by each village head in Pasuruan is Rp. 1.350.000.000 (1.35 billion). This value is very large and needs management and supervision in a transparent and accountable manner.

Coordination with the Community Empowerment Board (Bapemas Pasuruan District). While coordination with BAPEMMAS Kabupaten Pasuruan obtained information that in the management and administration of village finance 341 villages in Pasuruan Regency has been fostered by the Government Audit Board (BPKP) East Java Province as pilot project, the implementation of village financial system (SISKEUDES), but the obstacles in the field is still low understanding of village apparatus in the implementation siskeudes, this is because the educational background of the village apparatus is still minimal, less familiar with the use of computer.

The implement of Group Discussion Forum with the Research Team and Surveyor to determine the steps down and detail the activities. Socialization of Village Financial Software to village treasurer in Pasuruan Regency. Siskeudes application has been implemented in 34,006 villages spread over 244 districts / cities. In accordance with President Jokowi's direction when inaugurated the opening of the National Coordination Meeting of Government Internal Supervision (Rakorwasnas PIP) at the State Palace on May 18, 2017, it is expected that all villages in Indonesia use Siskeudes application in order to make village financial management more transparent and accountable.

Socialization of Village Financial Management software developed in this research is the development of software that has been created by BPKP, where in the SISKEUDES system is designed by BPKP not in detail include the application of tax calculation. The implementation of this software socialization was conducted at Merdeka Campus Pasuruan Regency by inviting 50 village treasurer.

The Village Fund initially divided into 3 (three) later stages of regulatory change, the Village Fund is channeled into 2 (two) stages that is in March and August. Regulation From the results of research by using interview techniques that indicate that the Village Fund from the Central Government down to the Government of Pasuruan District with implementers such as:

1. The transfer of the State General Treasury Account (RKUN) to the Regional General Treasury Account (RKUD) with the following requirements:

- Regional Regulation (Perda) on APBD 2016

- Bupati (Perbup) Regulation on Village Funds in 2016 
- Report on the disbursement and consolidation of the use of Village Funds in 2015 .

1. Pasuruan Regency Government has no burdensome requirement because these requirements are met and in the distribution which can be said to be classified smoothly. In the disbursement of Village Funds already in the Regional General Treasury Account (RKUD) to immediately arrive at the Village Cash Account (RKD) by going through two stages:

a) The first phase of 60\% (sixty percent) in March. Village Funds in 2016 Phase I until June. To be able to carry out the first phase then the Village Government / Village Head must meet the requirements that have been set namely: a. Make a Village Decree (Perdes) on APBDes year 2016b. Reports on realization of the previous year's Village Fund or in 2015 shall be submitted to the Regent of Pasuruan Regency.

b) The second phase by $40 \%$ (forty percent) in August. Village Fund Phase II in 2016 to the village in November. To be able to carry out the second phase then the Village Government / Village Head must make:

a. The report on the realization of the use of Stage One Village Funds per June 30 that shows the Village Fund has been used to reach 50\% (fifty percent). If the report on the realization of the use of Village Fund has not reached $50 \%$ then the disbursement of Village Fund in the second phase will be delayed.

c. Planning and compilation of APBDes in Pasuruan VILLAGE through stages:

- Preparation of the Village Mid-Term Development Plan (RPJMDes) by combining the vision of village and regional missions based on suggestions from below. The proposal is the aspiration of the community, then the village accommodates all the aspirations that have been entered on the side of the village in accordance with the need for their survival.

- Then the village holds a Village Development Planning Meeting (Musrenbang) aimed at establishing the priority scale in development that is accommodated in the form of the Village Government Work Plan (RKP).

- The preparation of the RKP is the basis for making the Village Revenue and Expenditure Budget Plan (RAPBdes).

- RAPBDes that have been set later in the Assistant to the Regent through the Village Financial Board (BKD).

- If it is correct and approved by the Regent, then set to APBDes.

\section{Usage and Accountability of Village Funds}


The use of the Village Fund should not be used in vain, therefore, the use of the Village Fund should begin with development planning, the allocation of Village Funds, the implementation of activities, the supervision of activities and the accountability of the use of the Village Fund. Sukorejo Village arranged a development plan in Sukorejo Village through: Village held Village Deliberation (MusDes). Based on the Musdes agreement led by the Village Consultative Board (BPD), the result of the Musdes is a reference for preparing the RPJMDes, RKPDesa, and the RKP proposal list. In the Musdes to accommodate all proposals from the community to plan the village development, the musdes is attended by the layers of society between other RT, RW and community leaders, for the Musdes was drawn up by RPJM and village RKP. In the village is divided into 4 (four) areas, among others are the areas of government, the field of development, the field of development and empowerment, before implementing the development and empowerment, the parties who carry out the development and empowerment submit proposal to the Village Head containing the Budget Plan) and details of required activities and budgets, after which the village verifies according to the budget received by the village, the village allocates funds to the beneficiary groups and villages as counterparts and evaluates in accordance with its activities and the groups get funds for activities by the way that they first submit a proposal along with the details of the budget. The budgeted activities are included in the RAPBDes after they are correct then submitted by the Village Government and the Village Consultative Board (BPD) are then submitted to the Regent to be inaugurated.

- Once everything is correct and propely done, then the RAPBDes is changed to APBDes which is the village reference to distribute the funds. Administratively, after the implementation of village activities is completed then each - each field both the field of empowerment and development in accordance with activities budgeted to make Letter of Accountability (SPJ). If the SPJ has been banar then it should be submitted to the treasurer and the village secretary to verify, then to the Village Head. Then the accountability is reported to the bupati in the Village Fund Fund Realization Report and archived at the Village Head Office if there is a sudden inspection from BPK. Monitoring and inspection from the Central Government suddenly, then the Examining Team asked for a coppy an SPJ of village fund which has been completed $100 \%$.

- Development of Village Financial Software 


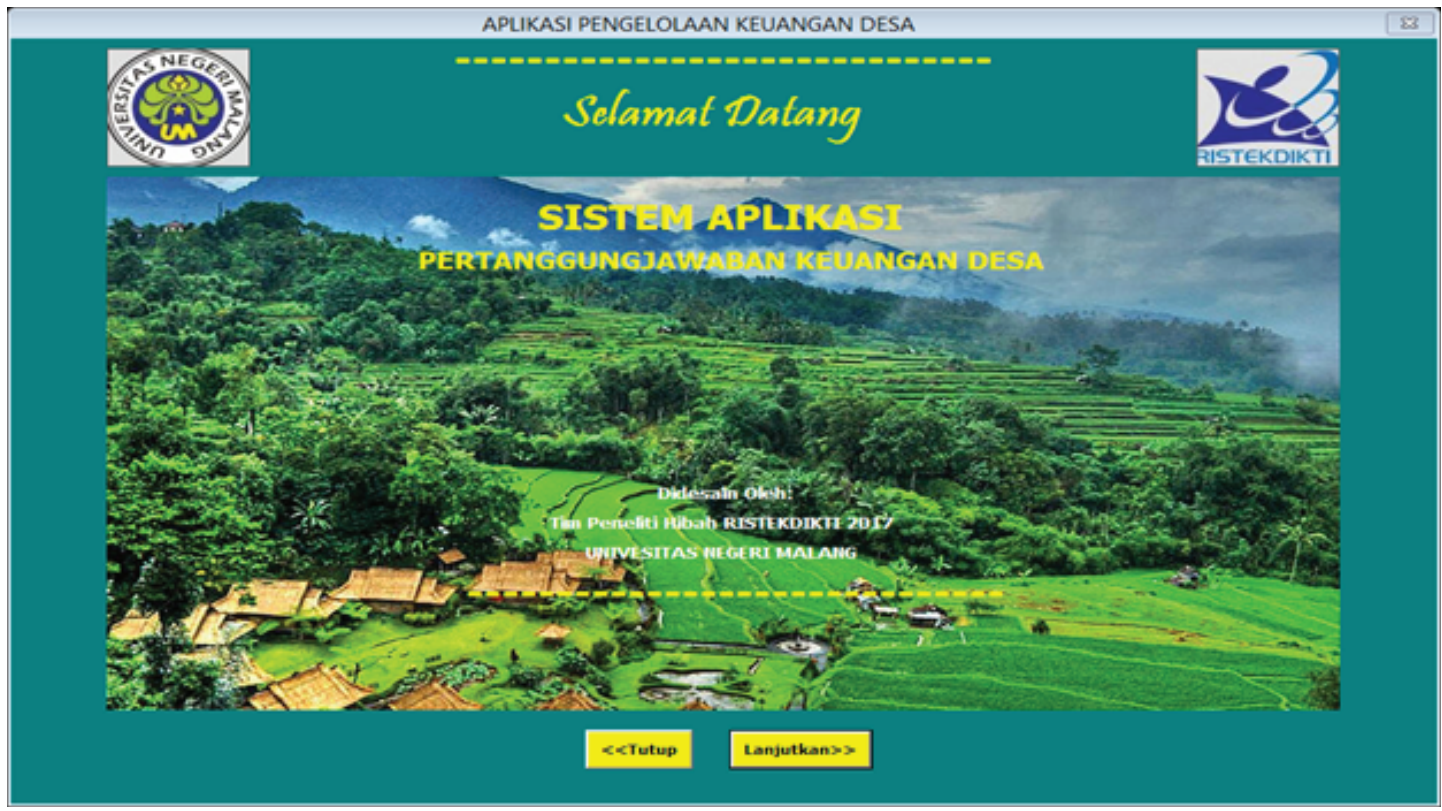

\section{CONCLUSION AND SUGGESTION}

\subsection{CONCLUSION}

The Village Law has delegated part of the government's authority to the village government in conducting village development. The success / failure of the village government in implementing village development is reflected in the village government's ability to manage village finances. The better the village government in doing financial management, the better the development in the village.

Portrait of village financial is recorded in the form of APBDesa that should be managed transparently, accountably, participatory and orderly and budget discipline in accordance with the legislation. APBDes as instruments of public policy has an important role and staregis for the village government in organizing the government and carry out development in the framework of service to the community. The preparation of APBDesa as part of the village financial planning and budgeting process also has a strategic position in village financial management. The success of the village government in preparing the APBDesa is the first step in the success of the next stage of village financial management. Therefore, a good understanding of the policy on the preparation of APBDesa is absolutely needed by the village apparatus as the executor of village financial management.

However, the problems that often arise in relation to the preparation of APBDesa a caused by several factors such as: 
- The weakness of human resources in understanding and implementing policy of APBDesa.

- The low skill of the village apparatus in using the computer

- Village financial software designed by BPKP still does not contain in detail the calculation of taxes that must be paid by the village treasurer.

- The problem of most of the village governments that can not arrange the APBDesa in accordance with the budget cycle timetable is more due to the scope of village government financial management and the village government's financial planning and budgeting cycle. Neither the scope of financial management nor the village government's planning and budgeting cycle is self-contained, but is tied to the scope of financial management and the supra-village planning and budgeting cycle. When there are constraints and problems in the government above it, will impact and also affect the village administration, in this case the preparation and determination of APBDesa

\section{SUGGESTION}

a. Improving the understanding and skill of the village apparatus in village-based IT financial management. Capacity building of villages in village financial management, especially the understanding of the policy of APBDesa preparation. In this case some emphasis approaches, such as: training and assistance for synchronization RPJMD and RKPD with RPJMDesa and RKPDesa and training and assistance for synchronization RPJMDesa, RKPDesa and APBDesa.

b. Placement of competent village assistants and understanding of village financial management in each village that can assist village apparatus in implementing village financial management.

c. In order to avoid delays in the information required for the preparation of the APBDesa, anticipatory measures are required in local regulations or regulations of regional heads, such as the policy of using the budget ceiling of the previous year before obtaining certainty of information from the government or local government. Then, making adjustments at the time APBDesa has changed its schedule. Thus, this will prevent the local government from delay in determining its APBDesa. 